\title{
Determinants of Courier Service Quality in e-Commerce from Customers' Perspective
}

\author{
DOI: 10.12776/QIP.V24I2.1438
}

\author{
Aleksandra Gulc \\ Received: 2020-03-30 Accepted: 2020-06-24 Published: 2020-07-31
}

\begin{abstract}
Purpose: In recent years, the increasing popularity of e-commerce has become a driving force behind the development of courier service both in Poland and worldwide. In order to face growing competition on courier market and meet clients' expectations, one of the crucial strategic goal of courier operators is to provide high quality service. The aim of the article is to identify and classify the key factors which determine the perception of courier service quality by customers shopping online.

Methodology/Approach: The first part of paper is focused on the literature review concerning the determinants of courier service quality from customers' perspective. Next, a survey method was used to collect data among customers using courier service while shopping online in Poland. Finally, the exploratory factor analysis was used to indicate the key dimensions and factors effecting the courier service quality perceived by customers.
\end{abstract}

Findings: The article presents the complex review of literature concerning determinants of courier service and the original scale, which can be used to measure courier service quality. The results of author's empirical research indicated that, the key dimensions effecting courier service quality from the customers point of view were: Reliability, Visual Identification, Service Complexity, Relational Capital, Social Responsibility, Responsiveness, Technical Quality.

Research Limitation/implication: As the research aim was to develop the scale of courier service quality, in future research the CFA method (Confirmatory Factor Analysis) should be used to verify the scale. The main limitation of this research concerned a perspective of one stakeholder participating in the process of courier service - e-clients. The further research would be focused on identification of determinants of courier service quality in opinion of online 
shops and courier companies and development of models presenting the relations between them.

Originality/Value of paper: This paper presents the original research that provides new knowledge about determinants of courier service quality in e-commerce. The literature analysis has shown that the previous research were often fragmentary and situational, but also did not take into account the specificity of e-commerce branch.

Category: Research paper

Keywords: courier service quality; determinants; e-commerce

\section{INTRODUCTION}

Courier service, which is a special kind of service within TSL sector, has recently become a critical link in logistics supply chains of many trading, manufacturing and service companies (Jarocka and Wang, 2018). Recently courier, express and parcel market (CEP) has developed dynamically worldwide and this trend will be maintained in the coming years. The value of the global courier market ammounted to 306 billion dollars in 2018, and according to forecasts it will reach 400 billion dollars by 2024, which means an increase of $8-10 \%$ annually (Statista, 2019). The value of European CEP sector has been growing recently by $7 \%$ annually while the volume of shipment by $8 \%$. As far as the market value is concerned, Germany, Great Britain and France are the leaders. Moreover, $80 \%$ of total revenues from courier service in Europe is generated in eight countries Germany, Great Britain, France, Spain, Italy, the Netherlands, Belgium and Poland (Dieke et al., 2019). Comparing to other European countries, the dynamics of CEP market value in Poland is one of the highest and it has increased by $11 \%$ annually. The growth rate of Polish courier market is three times faster than GPD in Poland. Nevertheless, the share of Polish CEP market has reached only $3 \%$ of European market value and the volume of shipments is eight times smaller comparing to Western countries. The experts predict that the growth of courier market in Poland will be developing much faster than in other European countries, which place Poland as a leader, next to Holland and Romania (Gawryluk, 2019).

Increasing popularity of online shopping has become one of the key driving force behind the development of courier service in recent years. A few years ago, courier companies were not interested in cooperation with e-commerce branch, because of the low scale of sales via Internet, the high fragmentation of deliveries and exceptional needs of individual customers. Since the opening of the World Wide Web for commercial use in 1995, the global value of e-commerce sales has continued to grow rapidly supported by increasing Internet connectivity, expanding global trade and more sophisticated shipping technology. In 2018, the value of global e-commerce market amounted to 2.3 trillion dollars, which meant $50 \%$ increase comparing to 2015 . It is presumed that the global value of the 
e-commerce market will grow dynamically over the next six years, reaching about $40 \%$ of the global market share in 2026. The growth rate of online sales will be more than four times faster than the total retail sales and $\mathrm{B} 2 \mathrm{C}$ service will continue to thrive the most among the segments of e-commerce sector (ITF, 2019).

In condition of rising popularity of online shopping, courier service is an crucial element effecting e-customers satisfaction and future intentions, but also e-retailers success (Jun, Yang and Kim, 2004; Kawa, Pieranski and Zdrenka, 2018; Liu et al, 2008; Micu, Aivaz and Capatina, 2013; Valaei, Rezaei and Shahijan, 2016; Yu et al., 2012). E-shoppers appreciate convenience of delivery, so they expect services that will suit their needs. Therefore, most of the largest courier operators prepare the offer dedicated to e-commerce branch. The options like multiple delivery choices, real time delivery information, possibility to reschedule the delivery or same-day delivery are among the interest of e-shoppers (Gulc, 2017a). As far as the delivery location is concerned, European e-customers chose home as the most popular one, while parcel shops were their second choice, which confirmed that they prefer convenience of delivery. Regular e-shoppers had positive experience with courier service $-78 \%$ of them considered the delivery of their latest online purchase was easy and $60 \%$ indicated that the latest returns experience was positive (DPD Group, 2019). With regard to the technology development, the courier service offer has evolved from traditional door-to-door delivery to a self-service based on non-human interfaces with the use of information technologies and modern logistics solutions (PWC, 2019). The final supervisor, which verify and evaluate the service offer, are clients. Thus, the courier service should not be treated as an offer of provider, but as a result of close cooperation with the customers. In client-oriented company, the customers should be perceived as one of resource bringing the essential information about their experiences, needs and expectations towards service quality (Prahalad and Ramaswamy, 2004; Grönroos, 2007; Grönroos and Ravald, 2011; Vargo and Lusch, 2004). Therefore, the further research concerning the service quality from the customers point of view, seems to be crucial and desired in condition of the evolution of courier service driven by e-commerce development and technology progress.

The aim of the article is to identify and classify the key factors which determine courier service quality perceived by clients shopping online. The main result of the research is the development of new scale which can be used as a measuring tool of courier service quality from the perspective of e-customers. The remainder of the paper consists of five sections. Section 2 presents the literature review on the issues relating to the aspects of courier service quality, especially the factors which determine the service quality and methods of measuring service quality. The analysed research were focused on the assessment of courier service quality from the perspective of business or individual clients. The results of the literature review served as a basis for the formulation of the list of potential factors determining the courier service quality in e-commerce. Section 3 
describes the research methodology, while the results and discussion are described in section 4 and 5. Finally, section 6 summarizes the findings and the conclusions briefly explaining the limitations of the research and implications for future research efforts.

\section{LITERATURE REVIEW}

This section presents the critical review of chosen publications concerning courier service quality especially the determinants and methods of measuring service quality. Although, CEP market has been constantly developing and the service quality is one of the key goals for courier operators, there are only a few articles concerning this issue both in the foreign and Polish literature.

Most of analysed research were based on SERVQUAL method in order to assess the service quality dimensions (tangibility, reliability, assurance, responsiveness and empathy) (Frą̧ś, 2014; Yee and Daud, 2011; Tabassum and Badiuddin, 2014; Yu et al., 2012). Yee and Daud (2011) examined the influence of dimensions of service quality on customers' satisfaction of parcel delivery. The research revealed that tangibility, reliability and assurance had an impact on customer satisfaction, while empathy and responsiveness had no significant effect on customer satisfaction. Similarly, Tabassum and Badiuddin (2014) based their research on SERVQUAL method in its original form, however they adjusted particular items to the specificity of courier service. The main objective of this study was to determine the gap between expectations and perception of service quality by customers. The highest gap was observed in case of reliability and responsiveness, so these issues should be strengthen by courier operators. The original theoretical approach presented $\mathrm{Yu}$ et al. (2012), who deliberated the method of courier quality service improvement called Two-Stage Quality Functional Deployment in order to transform express service demand into the express service resources. This research was focused on eliminating internal factors, which adversely affected service quality within the enterprise, but it did not verify their influence on service quality perceived by clients. Although, this method was verified in express industry, the authors suggest that it can be adopted to other branches of service sector.

Although the SERVQUAL is the most popular method of service quality measuring, it is also widely criticised because of its general character, so it requires modification to the specificity of particular service type. Moreover, the method does not distinguish the difference between satisfaction and service quality itself. The critics also undermined the main assumption of this method concerning the overall service quality which is calculated as the difference between expected and perceived quality. In fact, the clients usually assess perceived service quality without the comparison with their expectations (Gulc, 2017b).Therefore, some authors used less complex method of measuring courier service quality perceived by clients. A few previous studies considered the specific features of courier service (Gulc, 2017c). Some authors used logistic 
service quality scale (Liu and Liu, 2014; Ho et al., 2012), while others try to develop an original set of dimensions of courier service (Valaei, Rezaei and Shahijan, 2016; Gulc, 2017c). The study of Liu and Liu was focused on the assessment of the express logistics service quality on the basis of SERVQUAL method but with the use of Logistic Service Quality (LSQ) scale including the following dimensions: reliability, protection, security, empathy and perception. The research results revealed that customers were not satisfied with the protection, reliability and empathy while express service (Liu and Liu, 2014). Ho et al. (2012) used the LSQ scale in order to determine the most important factor of courier service quality effecting customers' satisfaction. The scale included the following dimensions: timeliness, condition/accuracy of order, quality of information and availability/quality of personnel. A multiple regression analysis indicated that timeliness, which was usually one of the most important dimension of courier service quality in other research, was replaced by condition/accuracy of order. The aim of study of Valaei, Rezaei and Shahijan (2016) was to determine the dimentions of courier service quality and the impact of perceived service quality on overall service quality. The study was based on SERVQUAL method, however the authors formulated the scale in the context of courier service titled as 'CouQual' including the following dimensions: promptness, convenience, accuracy, safety, and tangibles. The research results implied that the most important factors were promptness, safety and convenience, while accuracy and tangibility did not positively contribute to perceived service quality. The authors suggested that the model should be implied in different countries in order to check if the culture of different country could effect the perception of courier service quality.

In Polish literature, there are only a few papers concerning courier service quality, some of them were concentred on B2B service (Chodak, Latus and Prałat, 2010; Chodak, 2013; Dmowski, Śmiechowska and Zelmańska, 2013) while others on B2C service (Frąś, 2014) or both B2B and B2C (Dyczkowska, 2011; Gulc, 2017c). The research of Frąs aimed to evaluate the perceived quality according to SERVQUAL scale. The research results showed that the lowest rated dimension was responsiveness, and the highest - tangibility (Frąś, 2014). Chodak, Latus and Prałat's research (2010) was concentrated on the evaluation of the cooperation between courier or postal operators and online shops. The clients assessed service quality taking into account timeliness, delivery damage and loss, but also courier attitude and time of settlement in case of cash payment. The respondents were more satisfied with courier service than traditional postal service. Chodak (2013) conducted further research on courier service in e-commerce in Poland. The results of the research confirmed that over $80 \%$ of the online shops assessed courier service quality very highly. Respondents indicated the following factors which influenced the choice of courier companies: timeliness of services, service price, competence and culture of couriers, time of reaction and tracking the shipment. Less important factors were: diversity of service, availability of a program for printing waybills and labels, the time of money return and the least important - flexibility of delivery time and the 
functioning of one nationwide phone number that guarantees quick contact (Chodak, 2013). Dmowski et al. tried to indicate the most important factors of courier service quality from the perspective of business clients. The research focused on the following dimensions of service quality: knowledge and competence of staff, level of customer service, time of response and time of delivery, communication between courier companies and clients, the willingness and engagement to solve problems. The results revealed that a high overall quality assessment depended on functional dimensions of service quality (Dmowski, Śmiechowska and Zelmańska, 2013). The research conducted by Dyczkowska (2011) was focused mainly on the identification of factors determining the choice of courier company, but also the assessment of service quality by customers and the reasons of their complaints. The results indicated the factors affecting courier service quality perceived by customers, in particular the time of order completion, service price, lack of damage, the offer complexity, low complaint level and the quality of customer service. Inspired by the Franceschini's concept of aging of quality indicators, Gulc carried out a pilot research concerning the present and future expectations of clients using courier service. On the basis of literature and current trends on courier market, the author prepared a set of thirteen factors determining the choice of courier service. The respondents - individual and business clients of courier companies in Poland, assessed the importance of each criteria nowadays and in in the perspective of the next 5-10 years. The results showed that the most important criteria for clients would be time of delivery, trust, flexibility and tele-technologies, while the price would be less important (Gulc, 2017c).

The literature review carried out on the courier service quality led to the following conclusions:

- The authors of analysed research have not developed a measuring scale of courier service quality in the context of e-commerce in B2C relation.

- The research conducted so far in relation to courier service were often fragmentary and situational - the analysed papers were focused on a narrow group of respondents, a selected region of country or only one of the quality criteria.

- The empirical research concerning CEP market in the context of e-commerce in Poland is very limited.

The review of the literature allowed to formulate the following research questions:

RQ1. Which factors significantly affect the courier service quality in e-commerce from the perspective of clients shopping online?

$R Q 2$. How can the factors affecting courier service quality be classified?

$R Q 3$. Which aspects of courier service are the most important for e-customers in the context of service quality? 


\section{METHODOLOGY}

In order to explain the phenomena, which is courier service quality and develop an original measuring scale, an exploratory factor analysis (EFA) was used. Such approach is particularly appropriate when the phenomena is poorly recognized in the literature and the researcher does not assume a priori hypothesis about factors or patterns of measured variable. The analysed research did not reflect the specific features of courier service in e-commerce sector so that the author decided to use the EFA method in order identify a set of latent constructs (dimensions) determining courier service quality and develop a measurement scale. The method is used by researchers to underlay a battery of measured variables, uncover the underlying structure of a relatively large set of variables and identify relationships between measured variables (Norris and Lecavalier, 2009; Fabrigar et al., 1999). The EFA method is often used in the field of logistics (Ryciuk, 2016; Leończuk, 2019) and management (Ejdys, 2018; Wipulanusat, Panuwatwanich and Stewart, 2017).

The empirical research process included three stages: the preparation of initial list of factors on the basis of literature review, the survey conducted among e-clients using courier service in Poland and statistical analysis of obtained data with the use of exploratory factor analysis.

On the basis of literature review presented in section 2 and available documents of courier operators, the author prepared the list of factors which could determine the courier service quality perceived by individual customers shopping online. The final questionnaire included 38 factors. The empirical research was conducted with the use of CAWI method among individual clients using courier service while shopping online in Poland. The research was conducted in the period of November 2018 till January 2019 and the final number of respondents, who took part in the research and completed the survey amounted 594 persons. In order to identify the determinants of courier service quality, the respondents were asked the following question: What is the impact of the following factors on the courier service quality in your opinion? To answer the question, the 7-point Likert scale was used (in which 1 - very weak and 7 - very strong impact on courier service quality).

The research sample included the similar proportion of women to men, with slight predominance of women $(52 \%)$ than men (48\%). Taking into account the age of respondents, the largest group included respondents at the age of $36-55$ years old (281 persons), which amounted approximately $47 \%$ of the total number of respondents. The second largest group consisted of e-customers aged 26-35 (22\%). The share of people between 18-25 years old (14\%) and those over 55 years old $(16 \%)$ was similar. The least numerous group included respondents below 18 years old $(0.34 \%)$. As far as the education level was concerned, the majority of respondents were persons with higher education - approximately $81 \%$, less numerous was the group with medium education $(17 \%)$, while the 
minority were those having primary and vocational level of education approximately $2 \%$.

The respondents participating in the survey represented all 16 voivodships and their distribution was in correspondence with the structure of the general population of e-clients in Poland. The largest number of respondents were inhabitants of more populated voivodships, where more online shops were located - mazowieckie (91 respondents), śląskie (57 respondents), małopolskie (48 respondents). The least number of respondents was observed in case of less populated voivodeships - lubuskie (22 respondents), opolskie and świętokrzyskie.

Most of respondents, who participated in the survey, used courier service very frequently - more often that once a month (almost $60 \%$ ), so they are the most reliable source of information. Over 30\% used it once a quarter and only about $7 \%$ of respondents used courier service very rare - once a year or even less.

In the first stage of the analysis, the assumptions for using the factor analysis were checked: requirement of test sample (minimum 200 respondents) and the number of variables (3-4 variables describing the potential construct). Both conditions in this research were met. Next, the correlation between the examined variables was analysed and it was stated that each variable significantly correlated with several other variables, which was also proved by the determinant of the correlation matrix amounting 0.00000000002424. The Bartlett sphericity test also indicted that the correlation matrix contained significant available correlations. Moreover, the high value of Kaiser-Mayer-Olkin criterion (approximately 1) was also the premise for exploratory factor analysis.

To determine the number of factors (dimensions), the principal components analysis was used. Using the Kaiser's criterion, which is called eigenvalue-greater-than-one rule, seven factors were distinguished, which explained over $66.12 \%$ of the output variance of the variables. Similar results were obtained using the Cattel method, based on a graph showing seven factors with eigenvalues greater than 1 . For a seven-factor solution, a factor analysis was carried out using the principal axis method with Varimax normalized orthogonal rotation. The principal axis method was chosen as it requires no distributional assumptions and may be used if data are not normally distributed (Fabrigar et al., 1999). Orthogonal rotations are appropriate when the purpose for the factor analysis is to generate factor scores or when the theoretical hypotheses concern uncorrelated dimensions. Among the orthogonal types of rotations, Varimax is generally regarded as best and is most often used (Fabrigar et al., 1999). Later, the factor loadings were analysed. According to Bedyńska and Cypryańska (2013), if the factor loading is greater than 0.4 , it means that this variable is strongly loaded with the factor. However in practice, higher values are taken as often as possible. In order to indicate the variables which have strong contribution into particular construct, only the factors with the value of factor loading over 0.5 were chosen to the analysis. Using the factor loading matrix, 
insignificant variables with factor values less than 0.5 were removed, among others: V1 - Modern transport fleet, V2 - Modern and functional ICT technologies, V9 - Attractive prices and discounts, V14 - Transparent procedures, documents and service standards, V15 - Simplicity of placing an order, V21 - Cultural and polite behaviour of employees, V22 - Security of transactions, V31 - Individualisation of the service, V32 - Paying full attention to customer, V33 - Ensuring that the interests of the client are realised. All analysis presented in this paper were done with the use of Statistica software.

\section{RESULTS}

In result of factor analysis, 27 variables were classified into seven hidden variables (constructs/factors). In the Table 1, there are presented factor loadings, which are numerical values that indicate the strength and direction of a factor on a measured variable, so they indicate how strongly the factor influences the measured variable.

In result of exploratory factor analysis, the new scale was developed including seven dimensions and variables determining courier service quality (Table 1). The validity of the questionnaire was measured with the use of Cronbach's alpha coefficient. The coefficient values reached high level (above 0.7 ) in case of all distinguished dimensions. Therefore, it can be concluded that the developed scale is a reliable measurement tool (Sagan, 2004).

Table 1 - Results of Exploratory Factor Analysis and Reliability of Scale

\begin{tabular}{|c|c|c|c|c|}
\hline Dimension & \multicolumn{2}{|c|}{ Variable } & \multirow{2}{*}{$\begin{array}{c}\begin{array}{c}\text { Factor } \\
\text { loadings }\end{array} \\
0.773\end{array}$} & \multirow{2}{*}{$\begin{array}{c}\text { Cronbach's alpha } \\
\text { coefficient }\end{array}$} \\
\hline \multirow[t]{5}{*}{ F1: Reliability } & V10 & Timeliness of delivery & & \\
\hline & V11 & Successful delivery attempt & 0.782 & \\
\hline & V12 & Compliance and completeness of delivery & 0.728 & \\
\hline & V13 & Lack of damage to the package & 0.785 & \\
\hline & V27 & Efficient and fast handling of order & 0.604 & \\
\hline \multirow{3}{*}{$\begin{array}{l}\text { F2: Visual } \\
\text { identification }\end{array}$} & V6 & Aesthetic and neat appearance of courier & 0.716 & \multirow[t]{3}{*}{$0 ., 784$} \\
\hline & V7 & Characteristic trade mark and uniform colour & 0.690 & \\
\hline & V8 & $\begin{array}{l}\text { Aesthetic and functional company branches } \\
\text { and pick-up points }\end{array}$ & 0.637 & \\
\hline \multirow{2}{*}{$\begin{array}{l}\text { F3: Service } \\
\text { complexity }\end{array}$} & V36 & Wide range of additional service & 0.785 & \multirow[t]{2}{*}{0.809} \\
\hline & V38 & Service diversity & 0.712 & \\
\hline \multirow{3}{*}{$\begin{array}{l}\text { F4: Relational } \\
\text { capital }\end{array}$} & V16 & Positive experience with courier service & 0.576 & \multirow[t]{3}{*}{0.868} \\
\hline & V17 & Positive feedback from other customers & 0.547 & \\
\hline & V18 & Positive image and brand of courier company & 0.715 & \\
\hline
\end{tabular}




\begin{tabular}{|c|c|c|c|c|}
\hline \multirow[t]{4}{*}{ Dimension } & \multicolumn{2}{|c|}{ Variable } & \multirow{2}{*}{\begin{tabular}{|c|}
$\begin{array}{c}\text { Factor } \\
\text { loadings }\end{array}$ \\
0.680 \\
\end{tabular}} & \multirow{4}{*}{$\begin{array}{l}\text { Cronbach's alpha } \\
\text { coefficient }\end{array}$} \\
\hline & V19 & Experience and credibility of courier company & & \\
\hline & V20 & Knowledge and competence of employees & 0.510 & \\
\hline & $\mathrm{V} 25$ & Trust in the courier company & 0.643 & \\
\hline \multirow{2}{*}{$\begin{array}{l}\text { F5: Social } \\
\text { responsibility }\end{array}$} & V4 & Ecological technical solutions & 0.693 & \multirow[t]{2}{*}{0.708} \\
\hline & V34 & $\begin{array}{l}\text { Courier company's involvement in social } \\
\text { actions }\end{array}$ & 0.574 & \\
\hline \multirow{6}{*}{$\begin{array}{l}\text { F6: } \\
\text { Responsiveness }\end{array}$} & $\mathrm{V} 23$ & Easy contact with the courier company & 0.611 & \multirow[t]{6}{*}{0.893} \\
\hline & V24 & $\begin{array}{l}\text { Efficient communication with courier company } \\
\text { employees }\end{array}$ & 0.773 & \\
\hline & V26 & $\begin{array}{l}\text { Accurate and clear information on the } \\
\text { conditions of service provision }\end{array}$ & 0.531 & \\
\hline & V28 & Efficient handling of returns & 0.604 & \\
\hline & V29 & $\begin{array}{l}\text { Readiness to react quickly to reported problems } \\
\text { and interference }\end{array}$ & 0.736 & \\
\hline & V30 & $\begin{array}{l}\text { Flexibility (choice and change of date and } \\
\text { place of service) }\end{array}$ & 0.543 & \\
\hline \multirow{3}{*}{$\begin{array}{l}\text { F7: Technical } \\
\text { quality }\end{array}$} & V3 & Modern ecological solutions & 0.513 & \multirow[t]{3}{*}{0.762} \\
\hline & V37 & Availability of the service & 0.579 & \\
\hline & V39 & Choice of the delivery method & 0.529 & \\
\hline
\end{tabular}

The research result revealed that among all examined dimensions effecting the courier service quality from the perspective of e-customers, Reliability was the most important (mean value - 6.67), followed by Responsiveness (mean value 6.15). Technical quality (mean value - 5.82) and Relational capital (mean value - 5.46) were also highly rated. On the other hand, Service complexity was assessed as neutral dimension (mean value - 4.40), while the least important was Visual identification (mean value -3.69 ) and Social responsibility (mean value 3.24) (Figure 1).

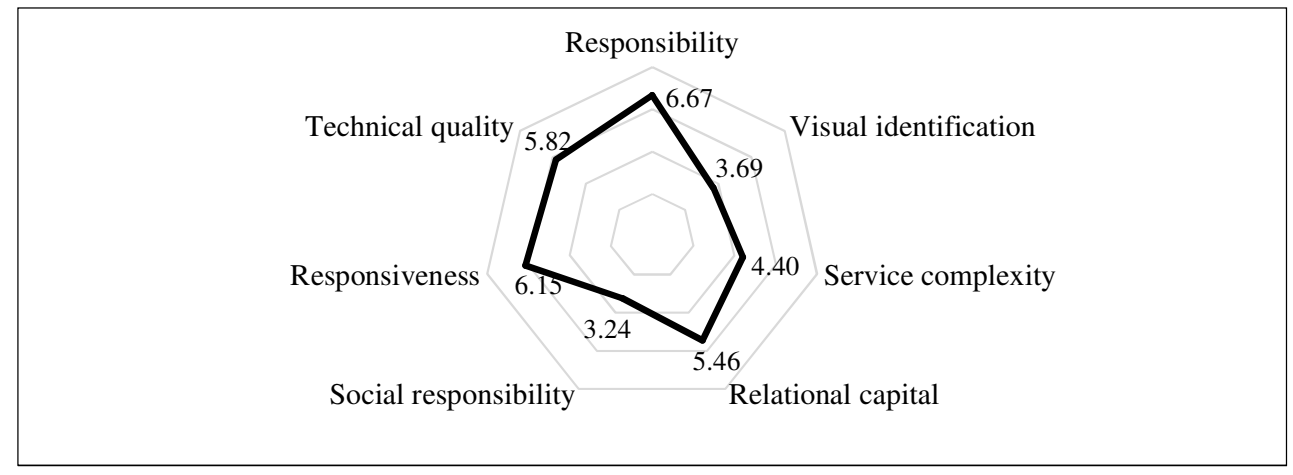

Figure 1 - Distribution of Means for All Dimensions of Courier Service Quality from e-clients' Perspective 


\section{DISCUSSION}

The research results indicate that courier service quality in e-commerce, which is analysed in the perspective of e-customers, is determined by the following dimensions:

F1: Reliability - contains the most important factors that affect courier service quality from the perspective of receiver, such as timeliness of delivery, successful attempt of delivery, compliance and completeness of the order, but also the lack of damage to the parcel, efficient and quick order processing;

F2: Visual identification - includes elements that create the image of courier company like aesthetic and neat appearance of courier, characteristic trademark and uniform colours, as well as aesthetic and functional company branches or Pick Up-Drop-Off locations (PUDO);

F3: Service complexity - is directly related to the offer of courier service including a wide range of additional service as well as the diverse scope and range of service;

F4: Relational capital - contains elements that contribute to long-term relationships between the courier company and clients, including the positive experience of clients using the courier service, opinions of other clients, as well as trust in the courier company, positive image and brand, experience and credibility, knowledge and competence of employees;

F5: Social responsibility - contains selected elements related to the social responsibility of courier companies, such as the involvement of courier companies in social actions and the use of ecological technical solutions (for example cars, electric drones, bicycles or ecological packaging);

F6: Responsiveness - is primarily associated with easy and efficient communication with the employees of the courier company, but also the willingness of employees to respond quickly to the problems and disruptions reported by the customers, efficient handling of return of ordered goods, providing accurate and clear information on the service terms and flexibility by ensuring that the date and place of delivery are selected or changed;

F7: Technical quality - includes selected elements related to the material aspects of the service like modern technical solutions dedicated for customers including the network of PUDO and parcel lockers and drones, the option of choosing the method of sending or delivery and the availability of service by providing a convenient location for PUDO and working hours.

The result of empirical research and statistical analysis indicated the determinants of courier service quality in e-commerce perceived by e-customers, which had not been mentioned in the analysed literature, especially relational capital and social responsibility. According to the obtained results, the most important dimension affecting courier service quality was reliability manifesting in timeliness, successful delivery attempt, completeness of delivery and lack of 
damage to the parcel. This tendency was also confirmed by other research (Ho et al., 2012; Valaei, Rezaei and Shahijan, 2016; Dyczkowska, 2011; Chodak, 2013). Similarly to other authors' studies, the research revealed that customers appreciated the responsiveness of staff while using courier service (Dmowski, Śmiechowska and Zelmańska, 2013). Moreover, the technical aspects of courier service were very important for e-customers, which is in accordance with other research conducted in Poland (Frąś, 2014) and at the same time on the contrary to the foreign research (Valaei, Rezaei and Shahijan, 2016). Taking into account the previously analysed papers, the developed scale revealed new aspects of courier service quality, which are important from the e-customers point of view.

\section{CONCLUSION}

In the light of the literature review, the study confirmed that there has not been elaborated a universal set of factors determining courier service quality. Their choice depended on the type of provided service, the segment of customers, but also the geographical and cultural area. This paper addressed an important and current research area that has not been sufficiently developed in the literature so far. The results of empirical research and statistical analysis revealed the determinants of courier service quality in e-commerce perceived by e-customers. On the basis of empirical research and conducted statistical analysis, 27 from 39 factors were classified according to 7 dimensions namely: Reliability, Visual Identification, Service Complexity, Relational Capital, Social Responsibility, Responsiveness and Technical Quality. The developed scale including dimensions and factors affecting courier service quality, need to be tested in order to be used as measurement tool in further research.

The main limitations of this research concerned a perspective of only one group of stakeholders participating in the process of courier service - e-clients. Therefore, the achieved results could be useful, serving as a starting point for the future research. The author intend to use CFA method (Confirmatory Factor Analysis) in order to test the hypothesis that a relationship between the observed variables and their underlying latent factors exists. The further research will be focused on identification of determinants of courier service quality in opinion of online shops and courier companies. The final result of all research steps will be the model of courier service quality in e-commerce presenting relations between three stakeholders participating in courier service (e-shops, courier company and final receivers).

\section{ACKNOWLEDGEMENTS}

The study was carried out as part of Research Project No. 2017/25/N/HS4/02051, titled "Relational model of quality shaping system of courier services in e-commerce", which was financed by the National Science Centre, Poland. 


\section{REFERENCES}

Bedyńska, S. and Cypryańska, M. eds., 2013. Statystyczny drogowskaz 1. Praktyczne wprowadzenie do wnioskowania statystycznego. Warszawa: Wydawnictwo Akademickie SEDNO.

Chodak, G., 2013. Metody dostarczania towarów przez polskie sklepy internetowe - wyniki badań. Gospodarka Materiałowa i Logistyka, 65(6), pp.21-32.

Chodak, G., Latus, Ł. and Prałat, E., 2010. Współpraca sklepów internetowych z przedsiębiorstwami kurierskimi i Pocztą Polską - wyniki badań. Gospodarka Materiatowa i Logistyka, 62(6), pp.18-26.

Dieke, A.K., Arnold, R., Bender, CH., Hillebrand, A., Niederprum, A. Taş, S., Tiele, S and Wielgosch, J., 2019. Development of Cross-border E-commerce through Parcel Delivery. [pdf] Luxembourg: Publications Office of the European Union. Availabe at: $<$ https://www.wik.org/fileadmin/Studien/2019/ET0219218ENN_ParcelsStudy_Fi nal.pdf $>$ [Accessed 30 April 2020]. DOI: 10.2873/931558.

Dmowski, P., Śmiechowska, M. and Zelmańska M., 2013. Jakość jako czynnik budujący przewagę konkurencyjną na rynku usług kurierskich. In: G. Rosa and A. Smalec, eds. 2013. Marketing przysztości. Trendy. Strategie. Instrumenty. Szczecin: Uniwersytet Szczeciński. pp.167-180.

DPD Group, 2019. E-shoppers in Europe: 2019 Barometer. [pdf] DPD Group. Available at: $<$ https://www.dpd.com/group/wpcontent/uploads/sites/77/2020/02/E-shoppers-in-Europe_2019Barometer_EN.pdf> [Assessed 30 May 2020].

Dyczkowska, J., 2011. Klient na rynku usług TSL. Zeszyty Naukowe Instytutu Ekonomii i Zarzadzania, Politechnika Koszlińska, 15, pp.119-134.

Ejdys, J., 2018. Zaufanie do technologii w e-administracji. Białystok: Oficyna Wydawnicza Politechniki Białostockiej.

Fabrigar, L.R., Wegener, D.T., MacCallum, R.C. and Strahan, E.J., 1999. Evaluating the use of exploratory factor analysis in psychological research. Psychological Methods, [e-journal] 4(3), pp.272-299. DOI: 10.1037/1082989X.4.3.272.

Frąś, J., 2014. Wybrane instrumenty pomiaru jakości usług logistycznych. Finanse, Rynki Finansowe, Ubezpieczenia, Zeszyty Naukowe Uniwersytetu Szczecińskiego, 66(803), pp.297-317.

Gawryluk, M., 2019. Rozwój rynku przesyłek kurierskich, ekspresowych $i$ paczkowych (KEP) w Polsce od 2014 r. do 2023 r. [online] Warszawa: Poczta Polska. Available at: <https://media.poczta-polska.pl/pr/465205/poczta-polskaw-2023-roku-rynek-kep-bedzie-mial-wartosc-12-mld-zl> [Accessed 12 May 2020]. 
Grönroos, CH., 2007. Service Management and Marketing: Customer Management in Service Competition. West Susex: John Willey \& Sons.

Grönroos, CH. and Ravald A., 2011. Service as business logic: implications for value creation and marketing. Journal of Service Management, [e-journal] 22(1), pp.5-22. DOI: 10.1108/09564231111106893.

Gulc, A., 2017a. Charakterystyka usług kurierskich w Polsce. Humanities and Social Sciences, 22(24), pp.61-75.

Gulc, A., 2017b. Models and Methods of Measuring the Quality of Logistic Service. Procedia Engineering, 18, pp.255-264.

Gulc, A., 2017c. Courier service quality from the clients' perspective. Engineering Management in Production and Services, [e-journal] 9(1), pp.36-45. DOI: 10.1515/emj-2017-0004.

Ho, J.S.Y., Teik, D.O.L., Tiffany, F., Kok, L.F. and Teh, T.Y., 2012. Logistic Service Quality among Courier Services in Malaysia. International Proceedings of Economics Development \& Research, 38(2012), pp.113-117.

ITF, 2019. ITF Transport Outlook 2019. [online] Paris: OECD Publishing. Available at: <https://www.oecd-ilibrary.org/transport/itf-transport-outlook2019_transp_outlook-en-2019-en> [Assessed 04 May 2019].

Jarocka, M. and Wang, H., 2018. Definition and classification criteria of logistics services for elderly. Engineering Management in Production and Services, [ejournal] 10(4), pp.65-75. DOI: 10.2478/emj-2018-0023.

Jun, M., Yang, Z. and Kim, D., 2004. Customers' perceptions of online retailing service quality and their satisfaction. International Journal of Quality \& Reliability Management, [e-journal] 21(8), pp.817-840. DOI: 10.1108/02656710410551728.

Kawa A., Pieranski B. and Zdrenka W., 2018. Dynamic Configuration of SameDay Delivery in E-commerce. In: A. Sieminski et al., eds. Modern Approaches for Intelligent Information and Database Systems. Studies in Computational Intelligence. Cham: Springer. pp.305-315. DOI: 10.1007/978-3-319-76081-0_26.

Leończuk, D., 2019. Ocena dokonań adaptacyjnego tańcucha dostaw. Białystok: Oficyna Wydawnicza Politechniki Białostockiej.

Liu, L. and Liu, CH., 2014. Empirical Study of Express Logistics Service Quality - A Survey of Changdao County Express Sector. In: ICETIS (International Conference on Education Technology and Information System), Proceedings of the 2014 International Conference on Education Technology and Information System (ICETIS 2014). Jinan, China, 26-27 April 2014. Atlantis Press. pp.542-546. DOI: 10.2991/icetis-14.2014.121. 
Liu, X., He, M., Gao, F and Xie, P., 2008. An empirical study of online shopping customer satisfaction in China: a holistic perspective. International Journal of Retail Distribution Management, [e-journal] 36(11), pp.919-940. DOI: 10.1108/09590550810911683.

Micu, A., Aivaz, K. and Capatina, A., 2013. Implications of logistic service quality on the satisfaction level and retention rate of an e-commerce retailer's customers. Economic Computation \& Economic Cybernetics Studies \& Research, 47(2), pp.147-155.

Norris, M. and Lecavalier, L., 2009. Evaluating the Use of Exploratory Factor Analysis in Developmental Disability Psychological Research. Journal of Autism and Developmental Disorders, [e-journal] 40(1), pp.8-20. DOI: 10.1007/s10803009-0816-2.

Prahalad, C.K. and Ramaswamy, V., 2004. Co-creation experiences: the new practice in value creation. Journal of Interactive Marketing, [e-journal] 18(3), pp.5-14. DOI: 10.1002/dir.20015.

PWC, 2019. Five Forces Transforming Transport \& Logistics, Trend Book. [pdf] PwC. Available through: <https://www.pwc.pl/pl/pdf/publikacje/2018/transportlogistics-trendbook-2019-en.pdf $>$ [Accessed 11 May 2020].

Ryciuk, U., 2016. Zaufanie międzyorganizacyjne $w$ tańcuchach dostaw $w$ budownictwie. Warszawa: Wydawnictwo Naukowe PWN SA.

Sagan, A., 2004. Badania marketingowe. Podstawowe kierunki. Kraków: Wydawnictwo Akademii Ekonomicznej w Krakowie.

Statista, 2019. Retail e-commerce sales worldwide from 2014 to 2023 (in billion U.S. dollars). [Industries $>$ E-Commerce > B2C E-Commerce]. Statista. [online] Availabe through: <https:/www.statista.com/statistics/379046/worldwide-retaile-commerce-sales/> [Assessed 10 March 2019].

Tabassum, R. and Badiuddin, A., 2014. Measuring the service quality gap in courier industry. IRJA-Indian Research Journal, 1(5), pp.1-11.

Valaei, N., Rezaei, S. and Shahijan, M.K., 2016. CouQual: assessing overall service quality in courier service industry and the moderating impact of age, gender and ethnicity. International Journal of Management Concepts and Philosophy, [e-journal] 9(2), pp.144-169. DOI: 10.1504/IJMCP.2016.077770.

Vargo, S.L. and Lusch, R.F., 2004. Evolving to a New Dominant Logic for Marketing. Journal of Marketing, [e-journal] (68)1, pp.1-17. DOI: 10.1509/jmkg.68.1.1.24036.

Wipulanusat, W., Panuwatwanich, K. and Stewart, R.A., 2017. Exploring leadership styles for innovation: an exploratory factor analysis. Engineering Management in Production and Services, [e-journal] 9(1), pp.7-17. DOI: 10.1515/emj-2017-0001. 
Yee, H.L. and Daud, D., 2011. Measuring Customer Satisfaction in the Parcel Service Delivery: a Pilot Study in Malaysia. Business and Economic Research, [e-journal] 1(1), pp.1-12. DOI: 10.5296/ber.v1i1.1125.

Yu, B., Zhang, S., Wu, S. and Xie, J.A., 2012. Study of Courier Service Quality Improvement Based on a Two-Stage QFD. In: Z. Zhang, R. Zhang and J. Zhang, eds., LISS 2012: Proceedings of 2nd International Conference on Logistics, Informatics and Service Science. Beijing, China, 12-15 July 2012. Berlin: Springer. pp.885-889. DOI: 10.1007/978-3-642-32054-5_123.

\section{ABOUT THE AUTHOR}

Aleksandra Gulc - Bialystok University of Technology, Poland, Faculty of Engineering Management, International Departament of Logistics and Service Engineering, e-mail: a.gulc@pb.edu.pl, Authors' ORCID: 0000-0002-64014765.

\section{CONFLICTS OF INTEREST}

The author declares no conflict of interest. The funder had no role in the design of the study; in the collection, analyses, or interpretation of data; in the writing of the manuscript, or in the decision to publish the results.

(C) 2020 by the authors. Submitted for possible open access publication under the terms and conditions of the Creative Commons Attribution (CC-BY) license (http://creativecommons.org/licenses/by/4.0/). 